\title{
MENTAL PROCESSES IN ALANI HAPOGOSAN MOVIE
}

\author{
*Slamet Rianto Resna Wanto \\ **Morada Tetty \\ **Rafika Dewi Nasution
}

\begin{abstract}
Wanto, Slamet Rianto Resna. 2141220023 Mental Processes in Alani Hapogosan Movie. A Thesis, English and Literature Department, Faculty of Languages and Arts. State University of Medan. 2018

The research was found on the topic about Mental Processes in Alani Hapogosan Movie. This study was aimed at identifying the types of mental process and the use of types of mental processes in Alani Hapogosan movie. This study was conducted by applying descriptive qualitative method. The source of data was taken from the conversation of Alani Hapogosan movie. The technique for analyzing the data is descriptive qualitative research based on Ary. The results of this research were types of mental processes in Alani Hapogosan movie which were Cognition (60,31\%), Perception (16,03\%), Desire (12,21\%) and Affection $(11,45 \%)$. The most dominat type of mental process was Cognition with percentage $60.31 \%$. The use of types of mental processes (Affection, Perception, Cognition, and Desire) was used based on the context in Alani Hapogosan movie.
\end{abstract}

Keywords: Mental Process, Movie, Alani Hapogosan Movie

*Graduate Status

** Lecturer Status

\section{INTRODUCTION}

Background of the Study

In social life, people know that language is one of the tools that human beings used for doing almost anything such as transmission of thoughts; ideas, feelings or information to other people. How people can interact with other is definitely by using language.

According to Halliday (2004:29) language is a system of meaning. That is to say that, when people use language, their language acts are the expression of meaning. The language can be categorized into spoken and written language. In doing interaction, spoken language is 
very important because through spoken language, people can express their feelings, and ideas, but in written language, they send their messages by using a sequence of letters, write poem or novel to express their feeling.

Many people study hard to master the language. However, they often ignore the essential aspects of the language. One of the aspects that should be known as in the function is verb. A verb is a word that expresses an action or state of being. According to Minneapolis (2001:10) says that a verb is a word used in sentence to explain what noun-a person, place, or thing-is doing or to explain what's being done to a noun. Verbs are much discussed in functional grammar which known as process.

According to Saragih (2004: 29) there are six types of process and it is divided into two parts. The first type is primary process which consists of material, mental, and relational. The second type is secondary process which consists of verbal, behavioral, and existential.

In social life, people know that language is one of the tools that human beings used for doing almost anything such as transmission of thoughts; ideas, feelings or information to other people. How people can interact with other is definitely by using language.

According to Halliday (2004:29) language is a system of meaning. That is to say that, when people use language, their language acts are the expression of meaning. The language can be categorized into spoken and written language. In doing interaction, spoken language is very important because through spoken language, people can express their feelings, and ideas, but in written language, they send their messages by using a sequence of letters, write poem or novel to express their feeling. 
Many people study hard to master the language. However, they often ignore the essential aspects of the language. One of the aspects that should be known as in the function is verb. A verb is a word that expresses an action or state of being. According to Minneapolis (2001:10) says that a verb is a word used in sentence to explain what noun-a person, place, or thing-is doing or to explain what's being done to a noun. Verbs are much discussed in functional grammar which known as process.

According to Saragih (2004: 29) there are six types of process and it is divided into two parts. The first type is primary process which consists of material, mental, and relational. The second type is secondary process which consists of verbal, behavioral, and existential.

In social life, people know that language is one of the tools that human beings used for doing almost anything such as transmission of thoughts; ideas, feelings or information to other people. How people can interact with other is definitely by using language.

According to Halliday (2004:29) language is a system of meaning. That is to say that, when people use language, their language acts are the expression of meaning. The language can be categorized into spoken and written language. In doing interaction, spoken language is very important because through spoken language, people can express their feelings, and ideas, but in written language, they send their messages by using a sequence of letters, write poem or novel to express their feeling.

Many people study hard to master the language. However, they often ignore the essential aspects of the language. One of the aspects that should be known as in the function is verb. A verb is a word that expresses an action or state of being. According to Minneapolis (2001:10) says that a verb is a word used in sentence to explain what noun-a person, place, or 
thing-is doing or to explain what's being done to a noun. Verbs are much discussed in functional grammar which known as process.

According to Saragih (2004: 29) there are six types of process and it is divided into two parts. The first type is primary process which consists of material, mental, and relational. The second type is secondary process which consists of verbal, behavioral, and existential.

While, according to Halliday (1994:112-119) mental processes are processes of sensing, in which participant, i.e conscious being or thing, is engaged in a process of seeing, feeling, or thinking, which may involve some other participants.

Process as grammatical features has been applied in many fields of subjects such as literary works which is consist of novels, movies, poem, song lyrics, and many other discourses.

Alani Hapogosan movie is Bataknese movie which tells about a poor man's life, and his struggle to pursue his ambition. The movie uses Bataknese language and use many mental processes. This is the reason of choosing Alani Hapogosan movie because it is a popular Bataknese movie nowadays. This movie can give many lessons for the viewers and it can inspire the viewers in life. From the movie, the researcher can take examples of mental processes;

Nai Sondang: Eee... Massohot majo sikkola na taon on eda. Marsikkor hioan do huala parnggoluan saonari on. So adong na mangrupi iba. Adong pe siadopan niba ai nga takkas boto eda holan marjuji dohot tenggen do karejona ganup ari. Bolong di kode ni sa angkat an. Eee.. sipata mandelele do au. 
' Nai Sondang: just let her to be homeless this year. Our live is very trouble, no one cares me. I have husband, and you know him so well. Everyday he plays gambling and he lives in that place. Sometimes my feeling's broken.

Here, the word of boto (know) belongs to mental process, and it is cognition.

The researcher believed that analyzing mental processes through movie was very interested. Because mental processes are talking about process of sensing, feeling, seeing, or thinking. According to Saragih (2004:31) says that mental process is one of linguistic resources which is potentially used to code characters. If people often use mental processes, they can build and develop their own good characters. The movie which told about sadness, happiness and poverty were only can be described by mental processes. From the explanation above, the researcher was interested in analyzing it. In terms of mental processes, the aspects to be analyzed were clauses representing perception, cognition, affection, and desire.

\section{REVIEW OF LITERATURE}

1. Systemic Functional Linguistics

According to Halliday (2017:32) says systemic functional linguistics is a tool to explore the specific type of linguistic choices that are used for some specific purposes. Systemic functional linguistics deals with metafunction.

a. Metafunction

The term of metafunction orginates in systemic functional linguistics and is considered to be a property of all languages. According to Systemic functional linguistics, functional bases of grammatical phenomenon are divided into three broad areas, called metafunctions: the ideational, the interpersonal, and the textual. 


\section{Transitivity}

Halliday (1994:106) says that the clause should be concerned and the experiential function as a way of represented patterns of experience. Language enables human beings to build a mental picture of reality, to make sense of what goes on around and inside. According to Martin, et al. (1997:102) describe transitivity as a resource for construing our experience in terms of configurations of a process, participant, and circumstances. The most powerful impression of experience is that consist of 'going on' happening, doing, sensing, meaning, being and becoming. These are represented as configuration experience of processes, participants, and circumstances.

\section{Processes}

Processes are realized by verbs. Traditionally verbs have been defined as "doing words". By definition, the term "process" refers in general to goings-on in reality, like doing, happening, seeing, feeling, thinking, being, having, etc. According to Martin, ET al. (1997: 102) divide six different process types in English. The three major ones are (1) material, (2) mental, (3) relational. In addition, there are three further process types : (4) behavioral, (5) verbal, and (6) existential.

\section{Mental Process}

Mental Process is process of sensing - process of consciousness. Halliday (2004: 14) divides mental process verbs into four classes namely: perception (perceiving through the five senses; hearing, seeing, etc.), affection (feeling, enjoying etc), cognition (thinking, understanding, knowing etc.), and desire (wondering, wishing etc).

1. Affection

2. Perception

3. Cognition
: like, delight, enjoy, etc

: smell, listen, hear, etc

: know, forget, think, etc 
4. Desire : wish, wonder, want,

\section{a. Perception}

Perception processes are realized by verbs as feel, listen, see, smell, taste, hear etc. It's related to our five senses like seeing, hearing, feeling, etc.

For examples:

1. I can see you tonight

2. You listened the music

3. My mother can smell the perfume

b. Cognition

Cognition process are realized by such stative verbs as believe, know, recognise, think, doubt, remember, forget, understand, etc. It is related to the process of happening in mind or thought like thinking, knowing, understanding, etc.

For examples:

1. He thinks about his mother

2. Zyan forgot the number

c. Affection

Affection processes are expressed by such as love, like, enjoy, dislike, hate, etc. Affectivity process has another type includes verbs which express such emotions as worry, surprise, dismay.

For examples:

1. She loves wearing necklace

2. I enjoy the music

3. He likes me

d. Desire

Desire processes comprise the verb wish, would rather, suppose. It is related to the process of expressing a wish, wants, request, etc. 
For examples:

a. He wants a cup of tea

b. I wish I can go home now

5. Alani Hapogosan Movie

Alani Hapogosan is included in real life movie. Alani Hapogosan is a BatakToba movie and original movie by Ponti Gea. Ponty Gea is a film producer who had graduated from Italy. He was Niasee who lived in Sibolga and he has a lot of family in Tapanuli. Alani Hapogosan movie was published on August 14th, 2015. The script of the movie was written by Bonardo Sinaga. Alani Hapogosan movie tells about a poor family who lived in small village. The main character of this movie is Sahat.

\section{RESEARCH METHODOLOGY AND FINDINGS}

\section{Research Methodology}

In conducting this research, the researcher used descriptive qualitative design. Ary, et al (2002: 25) stated that qualitative research Qualitative method was used to understand a phenomenon by focusing on the total picture rather than breaking it down into variables. The researcher used this method because it attempted to describe the linguistics phenomena found in a movie. In this research, the descriptive qualitative design was used to analyze the types of mental processes and the most dominant of mental process in Alani Hapogosan Movie.

Techniques of Collecting Data.

In collecting the data, the researcher did these following steps:

1. Downloading the data from internet to get the script of "Alani Hapogosan Movie" 
2. Watching the movie and writing the utterances into script

3. Reading the script of Alani Hapogosan Movie

4. Identifying all the mental processes uttered in the movie

\section{Techniques of Analyzing Data}

After collecting all the data of mental processes in Alani Hapogosan movie, the data were analyzed as follows:

1. Elaborating the theories and anything related to the problems

2. Identifying the mental processes in the movie

3. Classifying the mental processes into four types: (1) perception, (2) affection, (3) cognition, and (4) desire

4. Counting the data in percentage from by using a simple formula.

$$
\begin{aligned}
& \mathbf{X}=\frac{F}{N} \mathbf{x} \mathbf{1 0 0 \%} \\
& \mathrm{X}=\text { The percentage of the obtained items } \\
& \mathrm{F}=\text { Frequency } \\
& \mathrm{N}=\text { The total number of mental process from all types }
\end{aligned}
$$

5. Finding out the most dominant type of mental processes

6. Elaborating the use of types of mental processes in Alani Hapogosan Movie.

$$
\text { FINDINGS }
$$

Based on the data analysis, the findings of this study were formulated as follows:

1. There are four types of mental processes that is found in Alani Hapogosan movie namely Affection, Perception, Cognition, and Desire. The total of 
clauses that found in the movie are $131(100 \%)$ clauses. There are 79 clauses $(60.03 \%)$ of Cognition, 21 clauses $(16.03 \%)$ of Perception, 16 clauses (12.21\%) of Desire, and 15 clauses (11.45\%) of Affection. The most dominant type of mental process used in Alani Hapogosan Movie is Cognition.

2. The use types of mental processes in Alani Hapogosan movie. The first is Cognition. The clause is "Pos do rohakku tu ho da anakku". The word of Pos is mental process which means believe and it belongs to Cognition. The second one is Perception. the clause is "Imaa. Dibege ho do kan ?". the word of dibege means hear and it belongs to Perception. The third one is Desire. The clause is "Naa, tulangmu naeng makkatai". The word of naeng means want and it belongs to Desire. The last is Affection. The clause is "Unang pola mabiar namboru". The word of mabiar means worry and it belongs to Affection.

\section{CONCLUSION AND SUUGESTIONS}

\section{Conclusion}

From the data analysis, the objectives of this research are to identify the types of mental processes, the most dominant type, and the use of types of mental processes. This research is conducted by using qualitative method which is making a description and the percentage of the result. It is found:

1. There are four types of mental processes are found namely Affection 15 clauses (11.45\%), Perception 21 clauses (16.03\%), Cognition 79 clauses (60.31\%), and Desire 16 clauses (12.21\%). The most dominat type of mental process is Cognition. 
2. The four types of mental processes (Affection, Perception, Cognition, and Desire) were used based on the context in Alani Hapogosan movie.

\section{Suggestions}

In accordance with the conclusion and the aim of the thesis the researcher gives some suggestion as seen in the following:

1) It is suggested that the students of Englih Department should have many references to help of understanding in transitivity system. It can be a good comprehension in Halliday theory about mental processes.

2) It is advised that everyone who wants to do research in Linguistics should relate to Systemic Functional Linguistics (SFL) especially on transitivity system, should have more interesting data such as analyzing mental processes in different movie to make a clearer about mental processes.

\section{REFERENCES}

Ary, D., Jacobs, L C., Sorenses. C., and Razavueh, A. 2010. Introductionto Research in Education (8"ed). USA: Wadsworth

Astari, Y. 2016. Mental Processes in the Postings of Humansofnys's Instagram Account: Bonding Humans Through Languag. Padang: State University of Padang.

Bloor, T. And M. Bloor. 1995. The Functional Analysis of English. New York: New York Arnold.

Bustam, M. 2011. Analyzing Clause by Halliday's Transtivity System. Jakarta: State University of Padang. Pinter.

Eggins, S. 1994. An Introduction to Systemic Functional linguistcs. London:

Eggins, S. 2004. An Introduction to Systemic Functional Linguistics. New York: Continum.

Halliday, M.A.K. 1985. An Introduction to Functional Grammar. London: Edward Arnold.Halliday, M.A.K and Ruqaiya. 
Halliday, M.A.K. 1994. An Introduction to Functional Grammar. New York: Oxford Universiy Press.

Halliday, M.A.K. 2004. Introduction to Functional Grammar. New York: Oxford Universiy Press.

Halliday, M.A.K. 2017. A Transitivity Analaysis of American President Donald Trump's J Inaugural Address . China: Northwestern Polytechnical University.

Halliday, M.A.K and C. Matthiessen. 2004. An Introduction to Functional Grammar. London: Arnold Publisher.

Martin, J.R., Matthiessen, C., and Painter, C. 1997. Working with Functional Grammar. Edwarda Arnold.

Saragih, A 2004. Bahasa Dalam Konteks Sosial. Program Pascasarjana. Medan: UNIMED.

Saragih, A. 2010. introducing Systemic Functional Grammar of English. Medan: State University of Medan. 